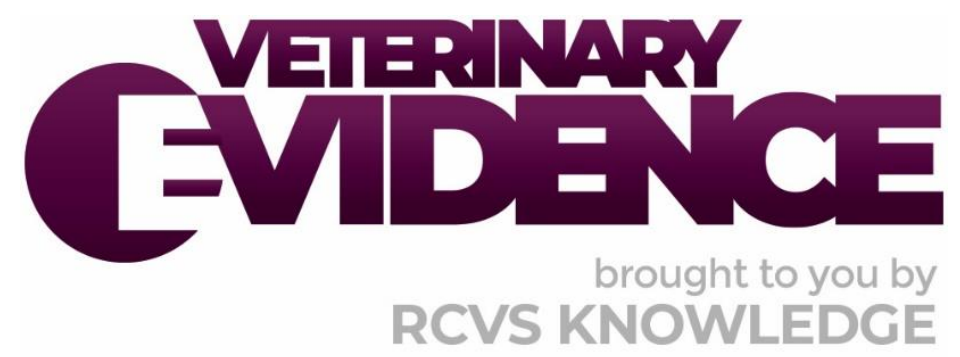

\title{
The incidence of uterine pathology in ovariectomised bitches
}

A Knowledge Summary by

Maria Norell Candetoft DVM ${ }^{1^{*}}$

\footnotetext{
1 Djursjukhuset AniCura Albano, Rinkebyvägen 21A, 18236 Danderyd, Sweden

* Corresponding Author (maria.norell.candetoft@anicura.se)
}

ISSN: 2396-9776

Published: 18 Sep 2020

in: The Veterinary Evidence journal Vol 5, Issue 3

DOI: 10.18849/VE.V5I3.331

Reviewed by: Soon Hon Cheong (DVM PhD) and Sebastian Patrick Arlt (Dipl ECAR)

Next Review Date: 24 Jan 2020 


\section{KNOWLEDGE SUMMARY}

\section{PICO question}

What is the incidence of postoperative uterine pathology in ovariectomised bitches compared to ovariohysterectomised bitches?

\section{Clinical bottom line}

\section{Category of research question}

Incidence

\section{The number and type of study designs reviewed}

Three retrospective case series

\section{Strength of evidence}

Weak

\section{Outcomes reported}

None of the reviewed case series found any uterine pathology for ovariectomised bitches in the long-term follow-up of several years, although none of the studies performed a proper gynaecological examination to confirm a lack of pathology

\section{Conclusion}

With the limited evidence available, it appears that leaving the uterus when gonadectomising bitches does not seem to have a high risk for developing pathology as long as the ovaries are completely removed

\section{How to apply this evidence in practice}

The application of evidence into practice should take into account multiple factors, not limited to: individual clinical expertise, patient's circumstances and owners' values, country, location or clinic where you work, the individual case in front of you, the availability of therapies and resources.

Knowledge Summaries are a resource to help reinforce or inform decision-making. They do not override the responsibility or judgement of the practitioner to do what is best for the animal in their care.

\section{Clinical Scenario}

You work at a small animal clinic and an owner comes to you with her intact female dog to discuss gonadectomy. She has heard that it is better to remove the uterus together with the ovaries because of the risk for the development of pyometra than to leave the uterus in the bitch. She wants to know your opinion on this subject. 


\section{The evidence}

Three papers were identified which addresses the PICO question and meet the inclusion and exclusion criteria applied. All three studies identified were retrospective case series. The number of cases included in the studies was moderately high: 278 (Corriveau et al., 2017), 264 (Okkens et al., 1997) and 72 (Janssens \& Janssens, 1991).

The studies describe short- and long-term outcomes after different surgical sterilisation methods in bitches: laparoscopic ovariectomy (LapOVE) and laparoscopic ovariohysterectomy (LapOVH) (Corriveau et al, 2017), ovariectomy and ovariohysterectomy via laparotomy and ovariectomy (Okkens et al, 1997) and bilateral flank ovariectomy (Janssons et al, 1991). All of the studies also include an owner questionnaire to identify long-term complications. The subjective nature of owner assessment may introduce bias.

Corriveau et al. (2017) compared the outcome between laparoscopic ovariectomy with ovariohysterectomy in 278 cases, the medical records were examined and responses to a questionnaire were developed and provided. None of the dogs in the two groups that were available during a 10 year follow-up (207 out of 278) developed clinical signs of uterine pathology.

Okkens et al. (1997) compared the outcome of 264 bitches that had been randomly selected for either ovariectomy or ovariohysterectomy. A questionnaire concentrated on the occurrence of problems related to abnormalities of the urogenital tract (i.e. vaginal discharge, attracting male dogs, and urinary incontinence) was sent to the owners 8 to 11 years after surgery. Complete data from 69 bitches in the ovariectomy group and for 66 bitches in the ovariohysterectomy group (135 out of 264) were available and analysed. No symptoms from the abdominal cavity as a consequence of the surgery were observed by any of the owners. Vaginal discharge was reported in two bitches in each group, the discharge was not severe and not accompanied by any apparent illness. Ovariectomy: discharge started 6 and 10 years after surgery, the discharge was colourless and was noticed in regular, but not cyclic, time intervals. Ovariohysterectomy: discharge started 3 months and 10 years after surgery, the discharge was whiteish and occurred regularly but not cyclic. Only one of these four bitches was presented to a veterinarian because of this problem, the article does not say what kind of diagnostics were used to examine the dog and no conclusion of the cause of the discharge is mentioned. None of the bitches were sexually attractive to male dogs after the sterilisation procedure.

Janssons \& Janssons (1991) described the outcome in 72 bitches that underwent bilateral flank ovariectomy, the owners received a questionnaire between 4 and 9 years after the operation and none of the bitches had developed pyometra.

\begin{tabular}{|l|c|c|c|c|}
\hline \multicolumn{1}{|c|}{ Article } & $\begin{array}{c}\text { Ovariectomy } \\
\text { (number) }\end{array}$ & $\begin{array}{c}\text { Ovariohysterectomy } \\
\text { (number) }\end{array}$ & $\begin{array}{c}\text { Follow-up time } \\
\text { (years) }\end{array}$ & $\begin{array}{c}\text { Uterine pathology } \\
\text { (\%) }\end{array}$ \\
\hline $\begin{array}{l}\text { Corriveau et al. } \\
(2017)\end{array}$ & 147 & 131 & $14 \mathrm{~d}-10 \mathrm{y}$ & 0 \\
\hline $\begin{array}{l}\text { Okkens et al. } \\
(1997)\end{array}$ & 126 & 138 & $8-11$ & 0 \\
\hline $\begin{array}{l}\text { Janssons \& } \\
\text { Janssons (1991) }\end{array}$ & 72 & 0 & $4-9$ & 0 \\
\hline
\end{tabular}


Even though the evidence presented in the three articles is far from the ideal grade I (meta-analyses of randomised, controlled trials or evidence obtained at least from one properly randomised, controlled trial), the high number of cases all presenting the same result, no signs of uterine pathology, is suggestive that leaving the uterus during gonadectomy does not appear to dramatically increase the occurrence of pyometra and may be considered reasonably safe. To raise the quality of the evidence, these bitches should have undergone a proper gynaecological examination.

\section{Summary of the evidence}

\begin{tabular}{|c|c|}
\hline \multicolumn{2}{|l|}{ Corriveau et al. (2017) } \\
\hline Population: & $\begin{array}{l}\text { Female neutered dogs, located in the USA, from } 125 \text { breeds. Most } \\
\text { common breeds included Great Dane (11\%), Labrador Retriever } \\
(10 \%) \text { and Golden Retriever ( } 6 \%) \text {. } \\
\text { Dogs were required to have undergone a LapOVH or a LapOVE. } \\
\text { Cases were excluded if records were incomplete, sterilisation was } \\
\text { performed because of a neoplastic process, or the dog was found to } \\
\text { have previously been sterilised. }\end{array}$ \\
\hline Sample size: & $\begin{array}{l}278 \text { dogs: } \\
\text { - } \quad \text { LapOVH } n=131 \\
\text { - } \quad \text { LapOVE } n=147\end{array}$ \\
\hline Intervention details: & $\begin{array}{l}\text { The medical record database of the Ryan Veterinary Hospital of the } \\
\text { University of Pennsylvania was reviewed to identify eligible cases. } \\
\text { The medical records from shelter-owned and client-owned female } \\
\text { dogs undergoing LapOVH or LapOVE during a } 14 \text { days to } 10 \text {-year } \\
\text { period from October } 2003 \text { through October } 2013 \text { were included. } \\
\text { Data collected from the medical record consisted of breed, age, } \\
\text { body weight, body condition score, history of urinary tract } \\
\text { abnormalities, preoperative systemic disease, number of } \\
\text { laparoscopic ports used, surgeon experience, total duration of } \\
\text { anaesthesia, LapOVE or LapOVH procedure time, additional } \\
\text { procedures performed, intraoperative surgical complications, } \\
\text { immediate postoperative complications, duration of hospitalisation, } \\
\text { and short-term postoperative incisional complications. } \\
\text { Long-term follow-up (>14 days to } 10 \text { years after surgery) to assess } \\
\text { postoperative complications and overall owner satisfaction was } \\
\text { conducted by means of a questionnaire administered by telephone } \\
\text { or email. } \\
\text { Questions were phrased to allow for initial 'yes' or 'no' } \\
\text { responses by the owner regarding postoperative } \\
\text { development of urinary incontinence, signs of oestrus, or } \\
\text { pyometra as diagnosed by a veterinarian. } \\
\text { If a complication was noted, additional information was } \\
\text { requested, including time of onset of clinical signs or } \\
\text { diagnosis, any diagnostic testing performed and any } \\
\text { treatment performed. }\end{array}$ \\
\hline Study design: & Retrospective case series \\
\hline
\end{tabular}




\begin{tabular}{|c|c|}
\hline Outcome studied: & $\begin{array}{l}\text { The short- and long-term follow up information regarding } \\
\text { complications after LapOVH vs LapOVE }\end{array}$ \\
\hline $\begin{array}{l}\text { Main findings: } \\
\text { (relevant to PICO question): }\end{array}$ & 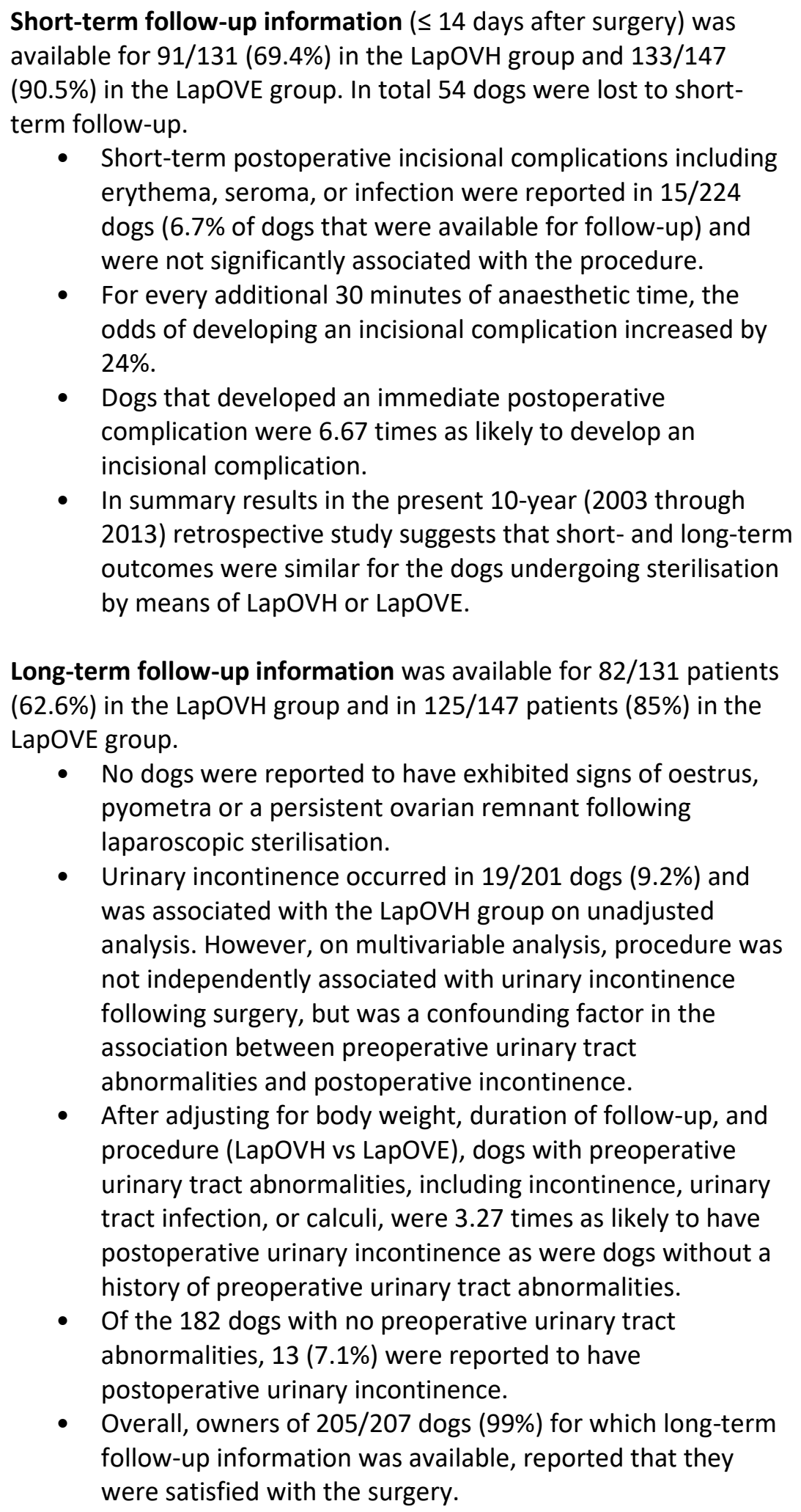 \\
\hline Limitations: & $\begin{array}{l}\text { - Retrospective case series provide low-level evidence. } \\
\text { - No other diagnostic tests were used to confirm that the } \\
\text { no vaginal cytology was done and no ultrasound of the } \\
\text { uterus was performed. }\end{array}$ \\
\hline
\end{tabular}




\begin{tabular}{|l|l|}
\hline - The study did not include laparotomy surgery. If removing \\
only the ovaries in open surgery affects the remaining uterus \\
it was not investigated. \\
- The article does not say how much time may have passed \\
since surgery and the performance of the questionnaire in \\
each individual case. \\
- In the LapOVE group approximately $37 \%$ of dogs were lost to \\
follow-up, in the LapOVH group 15\% of dogs were lost to \\
follow-up. Since the fate of the dogs lost at follow-up can't \\
be assessed it can't be estimated if there are more \\
complications with one method or the other.
\end{tabular}

Okkens et al. (1997)

\begin{tabular}{|c|c|}
\hline Population: & $\begin{array}{l}\text { Female neutered dogs, located in the Netherlands. Breeds } \\
\text { represented with more than six bitches were German Shepherds } \\
\text { (11), Bouviers des Flandres (11) and Dobermanns (8). The age of the } \\
\text { bitches at the time of surgery ranged from 0.8-9.9 years (median } 1.5 \\
\text { years) in the ovariectomy group and from 1.0-12.0 years (median } \\
2.5 \text { years) in the ovariohysterectomy group. All bitches had } \\
\text { experienced at least one oestrus before neutering. The body mass at } \\
\text { the time of the surgery ranged from } 1.6 \text { to } 37.5 \mathrm{~kg} \text { (median } 22.0 \mathrm{~kg} \text { ) } \\
\text { in the ovariectomy group and from } 5.0 \text { to } 37.5 \mathrm{~kg} \text { (median } 20.5 \mathrm{~kg} \text { ) in } \\
\text { the ovariohysterectomy group. } \\
\text { Cases were excluded if records were incomplete, sterilisation was } \\
\text { performed because of a neoplastic process or the dog was found to } \\
\text { have previously been sterilised. }\end{array}$ \\
\hline Sample size: & $\begin{array}{l}264 \text { neutered dogs: } \\
\text { - } 126 \text { ovariectomised } \\
\text { - } 138 \text { ovariohysterectomised }\end{array}$ \\
\hline Intervention details: & $\begin{array}{l}\text { - A questionnaire was sent to } 264 \text { owners of bitches as follow- } \\
\text { up to a routine neutering procedure performed } 8 \text { to } 11 \text { years } \\
\text { earlier. } \\
\text { - The bitches were randomly selected for either ovariectomy } \\
\text { or ovariohysterectomy. } \\
\text { - Both the ovariectomy group and the ovariohysterectomy } \\
\text { group were neutered through a caudal midline incision. } \\
\text { - Complete data analysis became available for } 69 \text { bitches in } \\
\text { the ovariectomy group ( } 54.7 \%) \text { and for } 66 \text { bitches in the } \\
\text { ovariohysterectomy group ( } 47.8 \%) \text {. } \\
\text { The questionnaires concentrated on the occurrence of } \\
\text { problems that could possibly be related to abnormalities of } \\
\text { abdominal organs, such as abdominal pain, and particularly } \\
\text { to abnormalities of the urogenital tract, i.e. vaginal } \\
\text { discharge, attraction of male dogs and urinary incontinence. } \\
\text { If an owner responded positively to one or more of the } \\
\text { questions, a detailed telephone interview concerning the } \\
\text { signs of the problem, duration and timing of the problem, } \\
\text { treatments, etc., was carried out. }\end{array}$ \\
\hline
\end{tabular}




\begin{tabular}{|c|c|}
\hline Study design: & Retrospective randomised case series \\
\hline Outcome studied: & $\begin{array}{l}\text { Comparison between differences in short-term and long-term } \\
\text { complications after ovariohysterectomy vs ovariectomy }\end{array}$ \\
\hline $\begin{array}{l}\text { Main findings: } \\
\text { (relevant to PICO question): }\end{array}$ & $\begin{array}{l}\text { - None of the bitches were sexually attractive to male dogs } \\
\text { after the neutering procedure. } \\
\text { - No abdominal problems as a consequence of the surgery } \\
\text { were observed by any of the owners. } \\
\text { Vaginal discharge was reported in two bitches in each group, } \\
\text { the discharge was not severe and not accompanied by any } \\
\text { apparent illness. } \\
\text { - Ovariectomy: discharge started } 6 \text { and } 10 \text { years after surgery, } \\
\text { the discharge was colourless and occurred regularly but not } \\
\text { cyclic. } \\
\text { Ovariohysterectomy: discharge started } 3 \text { months and ten } \\
\text { years after surgery, the discharge was whitish and was } \\
\text { noticed in regular but not cyclic time intervals. } \\
\text { - There were no significant difference between the } \\
\text { ovariectomy and ovariohysterectomy group in the incidence } \\
\text { of urogenital problems listed during the follow-up period of } \\
8 \text { to } 11 \text { years. } \\
\text { Ovariectomy does not increase the risk of cystic endometrial } \\
\text { hyperplasia (CEH) - endometritis or other complications } \\
\text { compared with ovariohysterectomy. }\end{array}$ \\
\hline Limitations: & $\begin{array}{l}\text { - It was a retrospective study, which is lower on the evidence } \\
\text { hierarchy compared to for example a randomised multi- } \\
\text { centre prospective study. } \\
\text { - No other diagnostic tests were used to confirm that the } \\
\text { remaining uterus was healthy; no blood samples were taken, } \\
\text { no vaginal cytology done and no ultrasound or other } \\
\text { diagnostic methods of the uterus was performed. } \\
\text { - The article does not say how much time may have passed } \\
\text { since surgery and the performance of the questionnaire in } \\
\text { each individual case. } \\
\text { In the ovariectomy group approximately } 45 \% \text { of dogs were } \\
\text { lost to follow-up, in the ovariohysterectomy group about } \\
42 \% \text { of dogs were lost to follow-up. Whether the dogs left } \\
\text { for follow-up developed uterine pathology or remained } \\
\text { healthy is not clear and must be taken into account. }\end{array}$ \\
\hline
\end{tabular}

Janssens \& Janssens (1991)

\begin{tabular}{|c|c|}
\hline Population: & $\begin{array}{l}\text { Ovariectomised female dogs from } 27 \text { different breeds. } \\
\text { The weight of the bitches at the time of surgery ranged from } 1.3 \text { and } \\
55 \mathrm{~kg} \text { (mean } 15.3 \mathrm{~kg} \text { ) and the age varied between } 0.5-7.0 \text { years } \\
\text { (mean } 2.2 \text { years). }\end{array}$ \\
\hline Sample size: & 72 dogs \\
\hline Intervention details: & $\begin{array}{l}\text { - The dogs underwent bilateral surgical flank approach and } \\
\text { the ovaries were removed. The surgery was performed } \\
\text { between } 1 \text { and } 4 \text { months after oestrus. }\end{array}$ \\
\hline
\end{tabular}




\begin{tabular}{|c|c|}
\hline & $\begin{array}{l}\text { - If uterine abnormalities were observed the uterus was also } \\
\text { removed. } \\
\text { - A questionnaire was handed out to } 72 \text { owners between } 4 \\
\text { and } 9 \text { years after the operation. } \\
\text { the questionnaires concentrated on the occurrence of long- } \\
\text { term problems: weight gain, hair-shedding, coat changes, } \\
\text { character changes, urinary incontinence and the } \\
\text { development of pyometra. }\end{array}$ \\
\hline Study design: & Non-comparative retrospective case series \\
\hline Outcome studied: & $\begin{array}{l}\text { Determination of short-term and long-term complications after } \\
\text { ovariectomy }\end{array}$ \\
\hline $\begin{array}{l}\text { Main findings: } \\
\text { (relevant to PICO question): }\end{array}$ & $\begin{array}{l}\text { In one dog an enlarged uterus was removed. In one obese dog the } \\
\text { ovarian bursa was not found on the left side. Therefore, a ventral } \\
\text { midline incision was used to approach this ovary. } \\
\text { Short-term complications: } \\
\text { - blood-loss from the surgical wound } 4 / 72(6 \%) \\
\text { - } \quad \text { seroma formation } 16 / 72(22 \%) \\
\text { - wound infection } 2 / 72(2.8 \%) \\
\text { - herniation (0\%) } \\
\text { Long-term complications: } \\
\text { - development of pyometra (0\%) } \\
\text { - weight gain } 43 / 72(60 \%) \\
\text { - } \text { coar-shedding } 19 / 72(26 \%) \\
\text { - changes } 5 / 72(6.9 \%) \\
\text { - towards other dogs } 16 / 72(22 \%) \\
\text { urinary incontinence } 13 / 72(18 \%)\end{array}$ \\
\hline Limitations: & $\begin{array}{l}\text { - No other diagnostic tests were used to confirm that the } \\
\text { remaining uterus was healthy; no blood samples were taken, } \\
\text { no vaginal cytology done and no ultrasound or other } \\
\text { diagnostic methods of the uterus were performed. } \\
\text { - There were no defined exclusion or inclusion criteria. } \\
\text { - The article does not say how the data from the short-term } \\
\text { complications were collected, did they see the animals at } \\
\text { the clinic or did they ask the owners? } \\
\text { - The article does not say how much time may have passed } \\
\text { since surgery and the performance of the questionnaire in } \\
\text { each individual case. }\end{array}$ \\
\hline
\end{tabular}


Only three studies were identified that addressed the PICO question and these studies were retrospective case series. Thus, the evidence base for answering the question is limited, but at least all three of the studies did not report a case where uterine pathology developed in an ovariectomised bitch.

Van Goethem et al. (2006) reviewed the outcome for ovariectomy and ovariohysterectomy, and they found that there was no difference in outcome when they analysed the present literature comparing the two methods. Ovariectomy did not lead to any pathologic changes in the remaining uterus. Bitches undergoing ovariectomy did not show symptoms of pyometra or endometritis years after the surgery.

In 1958, Dow reported the ability to experimentally induce cystic endometrial hyperplasia (CEH) or CEHendometritis by administration of progesterone, even in ovariectomised bitches. Withdrawal of the progesterone treatment causes regression of the experimentally produced disease. Similarly, ovariectomy leads to regression of the natural disease (Dow, 1958), thus exposure to progestogen appears to be necessary for the development of $\mathrm{CEH}$-endometritis and that is the main proposed answer to why the uterus seems to remain healthy after ovariectomy (Okkens et al. 1997).

Stump pyometra have been reported in bitches that have had an improperly performed ovariohysterectomy in association with ovarian remnant syndrome, breaks in aseptic technique, or exogenous progesterone administration (De Tora \& McCarthy, 2011; Van Goethem et al., 2006; Janssens \& Janssens, 1991; and Okkens et al., 1997).

Uterine neoplasia can develop after ovariectomy; however, uterine tumors are reportedly rare $(0.03 \%)$ and are benign in $85 \%$ to $90 \%$ of the cases (Brodey, 1967). Therefore, the overall risk has to be balanced against the disadvantages of ovariohysterectomy compared with ovariectomy in terms of surgical time, additional trauma, and potential complications.

It is important to note that none of the articles reviewed performed any diagnostic tests as part of the followup, and all three articles relied solely on owner responses to the questionnaires for data on uterine pathology or ovarian remnants. Also, in the study by Corriveau et al. (2017) $15 \%$ of the patients in the group that underwent ovariectomy were lost to follow-up and in the study by Okkens et al. (1997) $45 \%$ of the ovariectomised patients were lost to follow-up and the status of the remaining uterus in those patients is unknown.

To bring more evidence to properly answer the PICO question, a randomised multi-centre prospective study should be done with active follow-up including diagnostic workup (ultrasound, vaginal cytology, luteinizing hormone (LH) test, anti-muellerian-hormone tests etc.) to confirm the lack of uterine pathology or ovarian remnant occurring for a period of at least 5 to 10 years after the surgery. 


\begin{tabular}{|c|c|c|}
\hline \multicolumn{3}{|l|}{ Search Strategy } \\
\hline $\begin{array}{l}\text { Databases searched and dates } \\
\text { covered: }\end{array}$ & $\begin{array}{l}\text { CAB } \\
\text { PubN }\end{array}$ & $\begin{array}{l}\text { stracts on the OVID interface 1973-2020 Week } 03 \\
\text { d accessed via the NCBI website 1910-Jan } 2020\end{array}$ \\
\hline Search terms: & 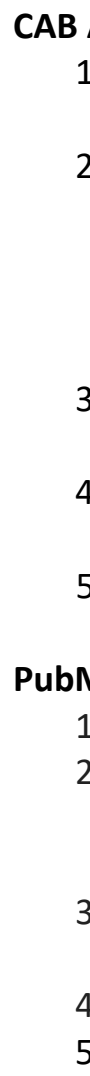 & $\begin{array}{l}\text { (dog or dogs or canine or canines or canis or bitch or bitches) or } \\
\text { exp dogs/ or exp bitches/ or exp canis/ } \\
\text { (spey* or spay* or neuter* or ovariectom* or } \\
\text { ovariohysterectom* or ovario-hysterectom* or hysterectom* } \\
\text { or sterilis* or steriliz* or desex* or de-sex* or gonadect*) or } \\
\text { exp ovariectomy/ or exp sterilization/ or exp hysterectomy/ or } \\
\text { exp gonadectomy/ } \\
\text { (pyometra or hydrometra or mucometra or uterine neoplasia or } \\
\text { endometrial hyperplasia) } \\
\text { ((uterine or uterus) and (disease* or pathology)).mp. or exp } \\
\text { uterine diseases/ } \\
1 \text { and } 2 \text { and ( } 3 \text { or } 4 \text { ) } \\
\text { (dog OR canine OR bitch OR canis) } \\
\text { (spey or spay or neuter or ovariectomy or ovariohysterectomy } \\
\text { or ovario-hysterectomy or hysterectomy or sterilise or sterilize } \\
\text { or desex or de-sex or gonadectomy) } \\
\text { (pyometra or hydrometra or mucometra or uterine neoplasia or } \\
\text { endometrial hyperplasia) } \\
\text { (uterine or uterus) and (disease or pathology) } \\
1 \text { and } 2 \text { and ( } 3 \text { or } 4 \text { ) }\end{array}$ \\
\hline Dates searches performed: & $24 \mathrm{Ja}$ & 2020 \\
\hline
\end{tabular}

\section{Exclusion / Inclusion Criteria}

\begin{tabular}{|l|l|}
\hline Exclusion: & - Non-English language \\
& - Wrong species \\
& - Articles not about uterine pathology after neutering \\
& - Conference proceedings and commentaries \\
\hline Inclusion: & - Only articles about uterine pathology after neutering \\
& - Full text articles available in English \\
& - Dogs only \\
\hline
\end{tabular}




\begin{tabular}{|c|c|c|c|c|c|c|}
\hline \multicolumn{7}{|c|}{ Search Outcome } \\
\hline Database & $\begin{array}{c}\text { Number } \\
\text { of } \\
\text { results }\end{array}$ & $\begin{array}{l}\text { Excluded - } \\
\qquad \text { Not } \\
\text { relevant to } \\
\text { the PICO } \\
\text { question }\end{array}$ & $\begin{array}{l}\text { Excluded - Not } \\
\text { in English }\end{array}$ & $\begin{array}{c}\text { Excluded - } \\
\text { Review papers, } \\
\text { proceedings, } \\
\text { conference } \\
\text { papers or book } \\
\text { chapters }\end{array}$ & $\begin{array}{c}\text { Excluded - } \\
\text { Wrong species }\end{array}$ & $\begin{array}{c}\text { Total } \\
\text { relevant } \\
\text { papers }\end{array}$ \\
\hline $\begin{array}{l}\text { CAB } \\
\text { Abstracts }\end{array}$ & 578 & 424 & 94 & 32 & 25 & 3 \\
\hline PubMed & 317 & 251 & 22 & 8 & 34 & 2 \\
\hline \multicolumn{6}{|c|}{ Total relevant papers when duplicates removed } & 3 \\
\hline
\end{tabular}

\section{CONFLICT OF INTEREST}

The author declares no conflicts of interest.

\section{REFERENCES}

1. Corriveau, K. M., Giuffrida, M. A., Mayhew, P. D. \& Runge, J. J. (2017). Outcome of laparoscopic ovariectomy and laparoscopic-assisted ovariohysterectomy in dogs: 278 cases (2003-2013). Journal of the American Veterinary Medical Association, 251(4):443-450.

DOI: https://doi.org/10.2460/javma.251.4.443

2. Brodey, R.S. (1967). Neoplasms of the canine uterus, vagina, and vulva: a clinicopathologic survey of 90 cases. Journal of the American Veterinary Medical Association, 151(10):1294-307.

3. De Tora, M. \& McCarthy, R.J. (2011). Ovariohysterectomy versus ovariectomy for elective sterilization of female dogs and cats: is the removal of the uterus necessary? Journal of the American Veterinary Medical Association, 239(11):1409-12. DOI: https://doi.org/10.2460/javma.239.11.1409

4. Dow, C. (1959). The cystic hyperplasia-pyometra complex in the bitch. Journal of Comparative Pathology and Therapeutics,, 69:237-250. DOI: https://doi.org/10.1016/S0368-1742(59)80023-0

5. Janssens, L. A. A. \& Janssens, G. H. R. R. (1991). Bilateral flank ovariectomy in the dog - surgical technique and sequelae in 72 animals. Journal of Small Animal Practice, 32(5):249-252.

DOI: https://doi.org/10.1111/j.1748-5827.1991.tb00557.x

6. Okkens, A.C., Kooistra, H.S. \& Nickel, R.F. (1997). Comparison of long-term effects of ovariectomy versus ovariohysterectomy in bitches. Journal of Reproduction and Fertility Supplement, 51:227-31.

7. Van Goethem, B., Schaefers-Okkens, A. \& Kirpensteijn, J. (2006). Making a rational choice between ovariectomy and ovariohysterectomy in the dog: a discussion of the benefits of either technique. Veterinary Surgery, 35(2):136-143. DOI: https://doi.org/10.1111/j.1532-950X.2006.00124.x 


\section{EVIIDEFeE

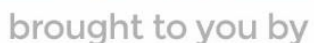 \\ RCVS KNOWLEDGE}

\section{Intellectual Property Rights}

Authors of Knowledge Summaries submitted to RCVS Knowledge for publication will retain copyright in their work, and will be required to grant RCVS Knowledge a non-exclusive license of the rights of copyright in the materials including but not limited to the right to publish, re-

publish, transmit, sell, distribute and otherwise use the materials in all languages and all media throughout the world, and to license or permit others to do so.

\section{Disclaimer}

Knowledge Summaries are a peer-reviewed article type which aims to answer a clinical question based on the best available current evidence. It does not override the responsibility

of the practitioner. Informed decisions should be made by considering such factors as individual clinical expertise and judgement along with patient's circumstances and owners' values. Knowledge Summaries are a resource to help inform and any opinions expressed within the Knowledge Summaries are the author's own and do not necessarily reflect the view of the RCVS Knowledge. Authors are responsible for the accuracy of the content. While the

Editor and Publisher believe that all content herein are in accord with current recommendations and practice at the time of publication, they accept no legal responsibility

for any errors or omissions, and make no warranty, express or implied, with respect to material contained within.

For further information please refer to our Terms of Use.

RCVS Knowledge is the independent charity associated with the Royal College of Veterinary Surgeons (RCVS). Our ambition is to become a global intermediary for evidence based veterinary knowledge by providing access to information that is of immediate value to practicing veterinary professionals and directly contributes to evidence based clinical decision-making.

https://www.veterinaryevidence.org/

RCVS Knowledge is a registered Charity No. 230886.

Registered as a Company limited by guarantee in England and Wales No. 598443.

Registered Office: Belgravia House, 62-64 Horseferry Road, London SW1P 2AF

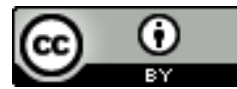

This work is licensed under a Creative Commons Attribution 4.0 International License. 